\title{
Effects of $\mathrm{CaO}$ and $\mathrm{Fe}_{2} \mathrm{O}_{3}$ on the Microstructure and Mechanical Properties of $\mathrm{SiO}_{2}-\mathrm{CaO}-\mathrm{MgO}_{-} \mathrm{Fe}_{2} \mathrm{O}_{3}$ Ceramics from Steel Slag
}

\author{
Lihua $\mathrm{ZHAO}^{1,2)} \mathrm{Yu} \mathrm{LI}^{1,2) *}$ Lingling $\mathrm{ZHANG}^{3)}$ and Daqiang $\mathrm{CANG}^{1,2)}$ \\ 1) State Key Laboratory of Advanced Metallurgy, University of Science and Technology Beijing, 30 XueYuan Road, Haidian \\ District, Beijing, 100083 China. $\quad$ 2) School of Metallurgy and Ecological Engineering, University of Science and Technol- \\ ogy Beijing, 30 XueYuan Road, Haidian District, Beijing, 100083 China. $\quad 3)$ School of Civil and Environmental Engineer- \\ ing, University of Science and Technology Beijing, 30 XueYuan Road, Haidian District, Beijing, 100083 China.
}

(Received on February 20, 2016; accepted on September 23, 2016; J-STAGE Advance published date: November 26, 2016)

\begin{abstract}
A new $\mathrm{SiO}_{2}-\mathrm{CaO}-\mathrm{MgO}-\mathrm{Fe}_{2} \mathrm{O}_{3}$ system ceramics, namely pyroxene ceramics in this paper, was put forward for efficiently utilizing the steel slag. The prepared ceramic with $30 \mathrm{wt} \%$ of steel slag has excellent properties with flexural strength of $107 \mathrm{MPa}$ and water absorption rate of $0.045 \%$. Microstructure evolution in the new system ceramics was studied by X-ray diffractometry and scanning electron microscopy. High content $\mathrm{CaO}$ in this system contributes to crystallization in low temperature. Diopside $\left(\mathrm{CaMgSi}_{2} \mathrm{O}_{6}\right)$ formed at temperature below $800^{\circ} \mathrm{C}$, and was predominant at approximately $1000^{\circ} \mathrm{C}$ before densification. The main phases of pyroxene have not changed except the solution of ions of $\mathrm{Fe}^{2+} / \mathrm{Fe}^{3+}, \mathrm{Al}^{3+}, \mathrm{Mn}^{2+}, \mathrm{Ti}^{4+}$ and so on. Melting of iron-rich andradite, $\mathrm{Fe}_{2} \mathrm{O}_{3}$ and $\mathrm{RO}$ (solution of $\mathrm{FeO}, \mathrm{MgO}, \mathrm{MnO}$ etc.) phases at temperature between $1100^{\circ} \mathrm{C}$ to $1180^{\circ} \mathrm{C}$ promoted liquid sintering and densification process. The crystallization process at temperature between $700^{\circ} \mathrm{C}$ to $1100^{\circ} \mathrm{C}$ is prior to the densification process at temperature between $1150^{\circ} \mathrm{C}$ to $1220^{\circ} \mathrm{C}$, and the formed crystals played an important role of framework during the densification process. Sole interlocking pyroxene phases and less glass phase in the final ceramic are contributed to its excellent mechanical performances.
\end{abstract}

KEY WORDS: steel slag; pyroxene ceramics; $\mathrm{CaO} ; \mathrm{Fe}_{2} \mathrm{O}_{3}$; strength; sintering; microstructure.

\section{Introduction}

Large amounts of Ca-rich or Fe-rich solid wastes, such as tailing, red mud, metallurgical slag and fly ash, have still not been efficiently utilized in the world. Steel making slag is a typical solid waste with high content of calcium and iron components. In China, 101 million tons steel slag were produced in 2013 , with only $22 \%$ reused, and the stockpile of steel slag has been accumulated to more than 400 million tons. ${ }^{1)}$ Such solid wastes have generated crucial problems for environment, because they not only occupy enormous land but also cause various pollutions to groundwater and soil. ${ }^{2)}$ It is of urgency to find solutions of technical and financial feasibility to minimize the impacts of such solid wastes on the environment and also convert them to useful materials.

Steel slag mainly consists of $\mathrm{CaO}, \mathrm{Fe}_{2} \mathrm{O}_{3}, \mathrm{SiO}_{2}, \mathrm{Al}_{2} \mathrm{O}_{3}$, $\mathrm{MgO}, \mathrm{MnO}$ and $\mathrm{P}_{2} \mathrm{O}_{5}{ }^{3)}$ There are a number of steel slag utilization methods, which are directed to the use of certain components or characteristic in steel slag, such as utilization in steel enterprise interior (for waste steel and $\mathrm{CaO}$ ), utilization for production of cement and concrete (for $\mathrm{CaO}$ and $\left.\mathrm{SiO}_{2}\right),{ }^{4)}$ utilization for materials of waste water treatment

* Corresponding author: E-mail: leeuu00@sina.com

DOI: http://dx.doi.org/10.2355/isijinternational.ISIJINT-2016-064 (for porous structure and large surface area) ${ }^{5)}$ utilization for road construction (for strength and shape), ${ }^{6}$ utilization for $\mathrm{CO}_{2}$ capture (for $\left.\mathrm{CaO}\right)^{7)}$ and so on. However, there are some limitations in these utilization methods. For example, steel slag cannot be directly reused in cement or concrete industry and road construction for potential dangers of instability and alkali aggregate reaction resulted from existence of free $\mathrm{CaO}$ and free $\mathrm{MgO} .^{8-10)}$

The ceramics appear a promising solution because it is able to convert, at a relatively low cost, complex chemical compositions into stable crystals or glass phase in ceramics. ${ }^{11-18)}$ Moreover, ceramics industry also has the ability to consume these bulk solid wastes besides cement and concrete industries. For instance, 10 billion square meter ceramic tiles were produced in China in 2014, the corresponding raw materials consumption was more than 300 million tons.

Traditional ceramics are a kind of aluminosilicate materials with main phases of mullite, quartz and glass phase. Clay, feldspar and quartz are its main raw materials. In recent years, ceramics prepared from solid wastes or industrial by-production have been studied. The involved solid wastes (industrial by-production) are typically steel slag, ${ }^{12}$ blast furnace slag, ${ }^{13,14,18)}$ municipal solid waste incinerator ashes, ${ }^{19)}$ and red mud. ${ }^{15)}$ Part of these studies focused on the experimental verification of possibility of a certain solid 
waste substituting for traditional raw materials. ${ }^{14,18)}$ However, the traditional ceramics belong to $\mathrm{SiO}_{2}-\mathrm{Al}_{2} \mathrm{O}_{3}-\mathrm{K}_{2} \mathrm{O}$ (and $\mathrm{Na}_{2} \mathrm{O}$ ) ternary system, and $\mathrm{Fe}_{2} \mathrm{O}_{3}$ and $\mathrm{CaO}$ are required less than $0.8 \mathrm{wt} \%$ and $3 \mathrm{wt} \%$ in the raw materials, respectively, because more addition of $\mathrm{Fe}_{2} \mathrm{O}_{3}$ and $\mathrm{CaO}$ would form more low temperature liquid and result in mechanical performance deterioration and sintering deformation. As steel slag has a composition of about $40-50 \mathrm{wt} \% \mathrm{CaO}$ and 20-25 wt $\% \mathrm{Fe}_{2} \mathrm{O}_{3}$, utilization of such solid wastes in ceramics with large proportion requires a new ceramics system with high $\mathrm{CaO}$ and/or $\mathrm{Fe}_{2} \mathrm{O}_{3}$ content. The other part of these studies focus on ceramic preparation of a certain or multiple solid wastes without proposing the corresponding ceramic system, ${ }^{13,20,21)}$ therefore limiting their potential applications to utilization of other solid wastes.

Some of authors ${ }^{22-24)}$ prepared high $\mathrm{CaO}$ and $\mathrm{Fe}_{2} \mathrm{O}_{3}$ content ceramics with excellent mechanical properties and its main phases were pyroxene group minerals. There are widely isomorphism phenomena in these minerals between ions, such as $\mathrm{Ca}^{2+}, \mathrm{Na}^{+}, \mathrm{Mn}^{2+}, \mathrm{Mg}^{2+}$ at position $\mathrm{M}_{2}, \mathrm{Fe}^{2+}$, $\mathrm{Mg}^{2+}, \mathrm{Mn}^{2+}, \mathrm{Ni}^{2+}, \mathrm{Li}^{+}, \mathrm{Al}^{3+}, \mathrm{Fe}^{3+}, \mathrm{Cr}^{3+}, \mathrm{Ti}^{3+}$ at position $\mathrm{M}_{1}, \mathrm{Si}^{4+}, \mathrm{Al}^{3+}$ at position $\mathrm{T}^{25)}$ This means that the pyroxene ceramics can produce in a wide range of composition, which could tolerate the usage of different alternative raw materials or various inorganic industrial solid wastes. Meanwhile, the heavy metal ion, such as $\mathrm{Mn}^{2+}, \mathrm{Ni}^{2+}, \mathrm{Cr}^{3+}, \mathrm{Ti}^{3+}$, could also be solidified in the pyroxene crystals. ${ }^{26)}$ Therefore the pyroxene ceramics have a great economic and environmental prospect in utilization of high $\mathrm{CaO}$ and/or $\mathrm{Fe}_{2} \mathrm{O}_{3}$ content solid wastes, such as steel slag, blast furnace slag, fly ash and red mud. However, as existence of considerable $\mathrm{CaO}$ and $\mathrm{Fe}_{2} \mathrm{O}_{3}$ in $\mathrm{SiO}_{2}-\mathrm{CaO}-\mathrm{MgO}-\mathrm{Fe}_{2} \mathrm{O}_{3}$ system ceramics, its sintering mechanism especially microstructure evolution related to $\mathrm{CaO}$ and $\mathrm{Fe}_{2} \mathrm{O}_{3}$ was still not clear, which is different from that of traditional $\mathrm{SiO}_{2}-\mathrm{Al}_{2} \mathrm{O}_{3}-\mathrm{K}_{2} \mathrm{O}$ (and $\mathrm{Na}_{2} \mathrm{O}$ ) system ceramics. The main purpose of the present study was to investigate the effects of $\mathrm{CaO}$ and $\mathrm{Fe}_{2} \mathrm{O}_{3}$ on microstructure and sintering evolution in the new system porcelain. This study may expand the potential applications to the utilization of other Ca-rich or/and Fe-rich solid wastes. X-ray diffractometry (XRD) and scanning electron microscopy (SEM) techniques were used for phase identification and microstructural study. Physical and mechanical properties were also discussed.

\section{Materials and Methods}

\subsection{Materials}

Raw materials used in the present investigation were steel slag (SS, supplied by ShanDong Iron and Steel Group,
China), clay, talcum and pyrophylite. Main chemical compositions as determined by X-ray fluorescence (XRF, XRF-1800, SHIMADZU, JAPAN) are in Table 1. Model porcelain bodies were prepared by mixing $30 \mathrm{wt} \%$ steel slag, $50 \mathrm{wt} \%$ talcum, $5 \mathrm{wt} \%$ pyrophylite and $15 \mathrm{wt} \%$ china clay (kaolin).

\subsection{Ceramics Manufacture Process}

Batches (400 g each) were wet-milled (with $400 \mathrm{ml}$ water) in a porcelain mill with alumina media for $40 \mathrm{~min}$ at $500 \mathrm{rpm}$. The slurry was passed through an $180 \mu \mathrm{m}$ mesh. The sieved slurry was then oven-dried overnight at $105^{\circ} \mathrm{C}$ and moistened by spraying with a fine mist of distilled water droplets (6-8 wt\%) and granulated through an $850 \mu \mathrm{m}$ mesh. The granulates were pressed at $80 \mathrm{MPa}$ in a steel die and the shaped samples $(50 \mathrm{~mm} \times 100 \mathrm{~mm} \times 7 \mathrm{~mm})$ were dried at $105^{\circ} \mathrm{C}$ for $12 \mathrm{~h}$. The dried samples were fired in an electrically operated laboratory furnace at constant heating rate of $5^{\circ} \mathrm{C} / \mathrm{min}$ and soaked for $6 \mathrm{~h}$ at the highest temperature in order to acquire a complete crystallization and then cooled to room temperature with furnace. These samples are referred to such as $\mathrm{Y} 0$ throughout this study, where $\mathrm{Y} 0$ is the as-mixed body and the number after $\mathrm{Y}$ denotes the relevant firing temperature.

\subsection{Physical Properties Tests}

The fired samples were subjected to physical tests of weight loss, linear shrinkage, water absorption and flexural strength (three-point bending). Linear shrinkage (LS) was determined the length difference between the green $\left(\mathrm{L}_{1}\right)$ and the fired material $\left(\mathrm{L}_{2}\right)$ by using Eq. (1):

$$
L S(\%)=100 \cdot\left(L_{1}-L_{2}\right) / L_{1}
$$

The water absorption (WA), measured according to ISO $10545-3,{ }^{27)}$ expresses the relationship of the mass of water absorbed $\left(\mathrm{M}_{2}\right)$ to the mass of dry sample $\left(\mathrm{M}_{1}\right)$ as Eq. (2):

$$
W A(\%)=100 \cdot\left(M_{2}-M_{1}\right) / L_{1}
$$

The flexural strength (R), measured according to ISO $10545-4,{ }^{28)}$ is calculated by Eq. (3)

$$
R(M P a)=3 \cdot F \cdot l /\left(2 \cdot b \cdot h^{2}\right)
$$

Where $\mathrm{F}$ is the breaking load $(\mathrm{N}) ; 1$ is the span between the support rods $(\mathrm{mm}) ; \mathrm{b}$ is the width of the test sample $(\mathrm{mm}) ; \mathrm{h}$ is the minimum thickness of the test sample measured after the test along the broken edge $(\mathrm{mm})$.

\subsection{Structure and Thermodynamic Analysis}

XRD analysis was performed using an automated dif-

Table 1. Main chemical compositions of the raw materials and initial mixture (wt $\%)$.

\begin{tabular}{crrrrrrrrrr}
\hline & $\mathrm{SiO}_{2}$ & $\mathrm{Al}_{2} \mathrm{O}_{3}$ & $\mathrm{MgO}$ & $\mathrm{CaO}$ & $\mathrm{Fe}_{2} \mathrm{O}_{3}$ & $\mathrm{~K}_{2} \mathrm{O}$ & $\mathrm{Na}_{2} \mathrm{O}$ & $\mathrm{TiO}_{2}$ & $\mathrm{MnO}^{2}$ & $\mathrm{Cr}_{2} \mathrm{O}_{3}$ \\
\hline SS & 14.45 & 2.03 & 5.83 & 53.04 & 19.20 & - & - & 0.78 & 2.36 & 0.46 \\
Pyrophylite & 76.95 & 22.13 & - & 0.03 & 0.16 & 0.36 & - & 0.16 & - & - \\
Talcum & 64.07 & 1.34 & 30.44 & 3.64 & 0.25 & 0.26 & 0.12 & 0.02 & 0.02 & - \\
Clay & 69.15 & 20.05 & 0.51 & 1.43 & 0.92 & 4.9 & 2.69 & 0.08 & 0.08 & - \\
Initial mixture & 50.59 & 5.39 & 17.05 & 17.95 & 6.03 & 0.88 & 0.46 & 0.26 & 0.73 & 0.14
\end{tabular}


fractometer (M21X, MAC Science Co. Ltd) at $40 \mathrm{KV}$ and $30 \mathrm{~mA}$ utilizing $\mathrm{CuK} \alpha$ radiation on powder samples sieved $<300$ grade mesh. The detector was scanned at a step size of $0.02^{\circ}$, a dwell time of $2 \mathrm{~s}$ per step, and a scan range from $15^{\circ}$ to $75^{\circ}$. The identification of all crystalline phases was undertaken with JADE6 software (Materials Data, USA) and the PDF-22004 database (International Centre for Diffraction Data, USA).

The fracture surfaces of the fired samples were investigated, using SEM (MLA250, FEI) at $20 \mathrm{KV}$ equipped with EDS (energy-dispersive spectrometry). The polished samples were etched with HF solution ( 5 vol\%) for $90 \mathrm{~s}$ at room temperature, immediately rinsed with deionized water in ultrasonic wave cleaner for $3 \mathrm{~min}$. All samples were coated with Pt. Secondary electron images (SEI), back-scattered electron images (BSI) were used to observe the apparent morphology and identify the constituent phases.

The purpose of the calculation of Gibbs free energy changes is to support the analysis of sintering process. Thermodynamic analysis was conducted by View Data model of FactSage 6.3 software.

\section{Results}

\subsection{Physical and Mechanical Properties}

Linear shrinkage, water absorption and flexural strength are monitored because these parameters are related to sintered bodies properties. The variation in linear shrinkage, water absorption and flexural strength with sintering temperature are shown in Fig. 1. The linear shrinkages of samples increase with heating temperature. However, the rate of increase in linear shrinkage is slow or nearly constant at low temperatures (below $1000^{\circ} \mathrm{C}$ ), but increases rapidly beyond $1100^{\circ} \mathrm{C}$, reaches the maximum $12.82 \%$ at $1220^{\circ} \mathrm{C}$, decreases at $1240^{\circ} \mathrm{C}$ because of overfiring. Dramatically change of linear shrinkage in the temperature range of $1150^{\circ} \mathrm{C}$ to $1220^{\circ} \mathrm{C}$ illustrates the occurrence of densification process in this temperature range. Generally, water absorption depicts a reverse trend to that of the linear shrinkage. The water absorption is high (above 10\%) at low temperatures (below $1150^{\circ} \mathrm{C}$ ), and nearly constant beyond $1220^{\circ} \mathrm{C}$ although the linear shrinkage and flexural strength has been changed at $1240^{\circ} \mathrm{C}$. Tendency of water absorption and flexural strength had confirmed the occurrence of densification process between $1100-1220^{\circ} \mathrm{C}$, which was in accordance with the linear shrinkage.

As shown in Fig. 1, three stages of sintering process of the ceramics were observed according to changes of their properties. Stage I (from $700^{\circ} \mathrm{C}$ to $1100^{\circ} \mathrm{C}$ ), which shown high water absorption, low flexural strength and linear shrinkage. Dramatically change in physical and mechanical properties at stage II suggested the densification process happened at temperature from $1100^{\circ} \mathrm{C}$ to $1220^{\circ} \mathrm{C}$. Stage III was named over-fired process because of expansion.

For the sample fired at $1220^{\circ} \mathrm{C}$ develops the highest flexural strength $107 \mathrm{MPa}$ and the lowest water absorption $0.045 \%$, which are much better than the requirements of porcelain about $\geq 35 \mathrm{MPa}$ for flexural strength and $\leq 0.5 \%$ for water absorption.

\subsection{XRD Analysis}

The phase changes in the fired experimental bodies were investigated by XRD analyses. Figure 2 shows the XRD patterns of unfired sample and samples fired at different temperatures. The XRD pattern of Y0 shows the complexity of the component, and major XRD peaks correspond to quartz, talcum, calcite, larnite and small peaks correspond to hematite. Quartz peaks shows decreasing trend with sintering temperature and only trace at $1150^{\circ} \mathrm{C}$. Anorthite was detected at $700^{\circ} \mathrm{C}$ and diopside was seen at $800^{\circ} \mathrm{C}$. Akermanite peaks were clearly seen at $900^{\circ} \mathrm{C}$, beyond which major akermanite peaks were disappeared and diopside became prominent at the same time. X-ray patterns of Y1000 sample shows diopside as the main phase. No obvious changes among X-ray patterns of samples sintering above $1100^{\circ} \mathrm{C}$, except the main phase changed from diopside in Y1100 to diopside aluminian in Y1150. The above results illustrated that the crystallization process completed at temperature blow $1150^{\circ} \mathrm{C}$. The evolution of calcium-rich and iron-rich crystalline phases will be further discussed below. The main phases and several other small peaks not marked in Fig. 2 were shown in Table 2.

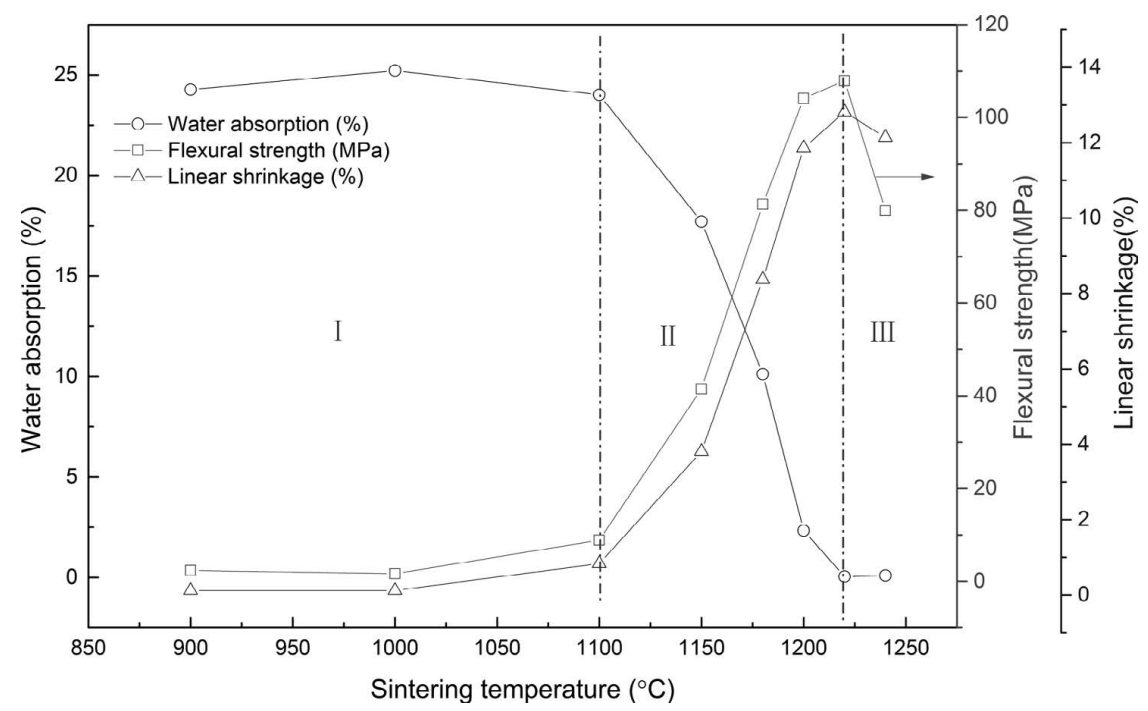

Fig. 1. Linear shrinkage, water absorption and flexural strength of samples sintered at different temperatures. 
(a)

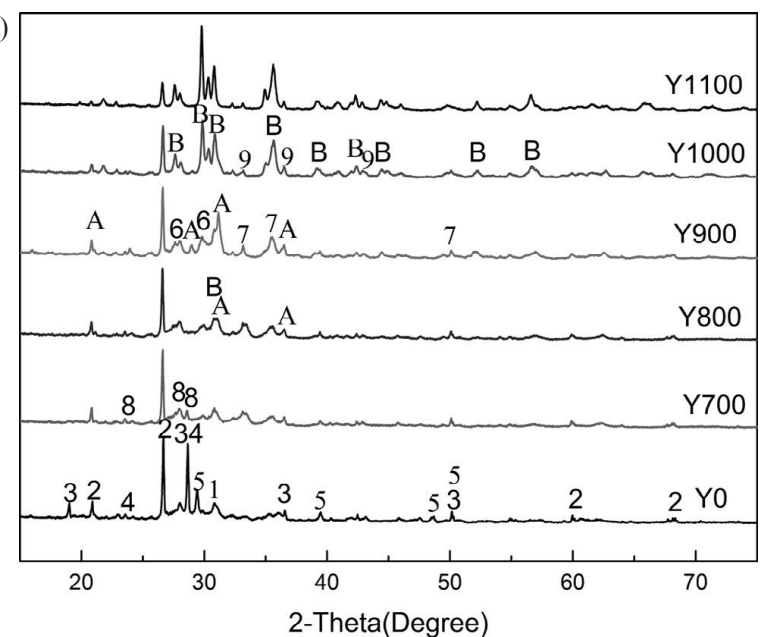

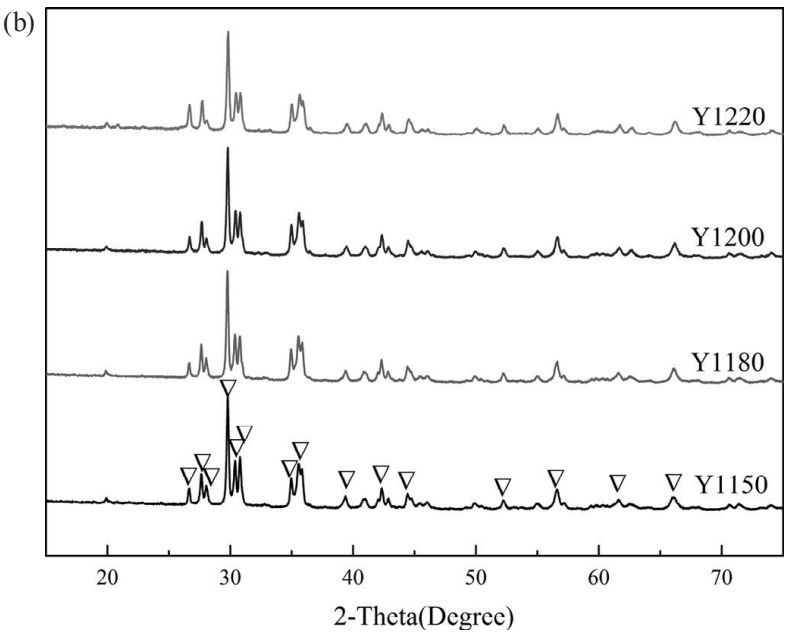

Fig. 2. XRD patterns of initial powder and samples sintered at different temperatures. Where: (a) 1-Larnite- $\mathrm{Ca}_{2} \mathrm{SiO}_{4}$; 2-Quartz; 3-Talcum- $\mathrm{Mg}_{3} \mathrm{Si}_{4} \mathrm{O}_{10}(\mathrm{OH})_{2} ; 4$ - $\alpha$-Quartz; 5-Calcite- $\mathrm{CaCO}_{3} ; 6$-Enstatite- $\mathrm{MgSiO}_{3} ; 7$-Hematite- $\mathrm{Fe}_{2} \mathrm{O}_{3}$; 8-Anorthite-Ca( $\left.\mathrm{Al}_{2} \mathrm{Si}_{2} \mathrm{O}_{8}\right)$; 9-Andradite- $\mathrm{Ca}_{3} \mathrm{Fe}_{2}\left(\mathrm{SiO}_{4}\right)_{3}$. A-Akermanite- $\mathrm{Ca}_{2} \mathrm{Mg}\left(\mathrm{Si}_{2} \mathrm{O}_{7}\right)$; B-Diopside-CaMgSi $\mathrm{O}_{6}$. (b) $\nabla$-Diopside aluminian- $\left(\mathrm{Mg}_{0.851} \mathrm{Fe}_{0.026} \mathrm{Al}_{0.080} \mathrm{Ti}_{0.003} \mathrm{Cr}_{0.040}\right)\left(\mathrm{Ca}_{0.720} \mathrm{Na}_{0.027} \mathrm{Mg}_{0.179} \mathrm{Fe}_{0.071} \mathrm{Mn}_{0.003}\right)\left(\mathrm{Si}_{1.891} \mathrm{Al}_{0.109}\right) \mathrm{O}_{6}$.

Table 2. Main phase of the samples.

\begin{tabular}{|c|c|c|c|c|c|c|c|c|c|}
\hline Main phases & Y700 & Y800 & Y900 & Y1000 & Y1100 & Y1150 & Y1180 & Y1200 & Y1220 \\
\hline Quartz- $\mathrm{SiO}_{2}$ & $\sqrt{ }$ & $\sqrt{ }$ & $\sqrt{ }$ & $\sqrt{ }$ & $\sqrt{ }$ & $\sqrt{ }$ & $\sqrt{ }$ & $\sqrt{ }$ & - \\
\hline Protoenstatite- $\mathrm{MgSiO}_{3}$ & $\sqrt{ }$ & $\sqrt{ }$ & $\sqrt{ }$ & $\sqrt{ }$ & $\sqrt{ }$ & $\sqrt{ }$ & $\sqrt{ }$ & $\sqrt{ }$ & $\sqrt{ }$ \\
\hline Calcium silicate- $\mathrm{Ca}_{2} \mathrm{SiO}_{4}$ & $\sqrt{ }$ & $\sqrt{ }$ & - & - & - & - & - & - & - \\
\hline Hematite- $\mathrm{Fe}_{2} \mathrm{O}_{3}$ & $\sqrt{ }$ & $\sqrt{ }$ & $\sqrt{ }$ & $\sqrt{ }$ & $\sqrt{ }$ & $\sqrt{ }$ & $\sqrt{ }$ & $\sqrt{ }$ & - \\
\hline Akemantite- $\mathrm{Ca}_{2} \mathrm{Mg}\left(\mathrm{Si}_{2} \mathrm{O}_{7}\right)$ & - & $\sqrt{ }$ & $\sqrt{ }$ & - & - & - & - & - & - \\
\hline Anorthite- $\mathrm{Ca}\left(\mathrm{Al}_{2} \mathrm{Si}_{2} \mathrm{O}_{8}\right)$ & $\sqrt{ }$ & $\sqrt{ }$ & $\sqrt{ }$ & $\sqrt{ }$ & $\sqrt{ }$ & $\sqrt{ }$ & $\sqrt{ }$ & - & - \\
\hline Forsterite- $\mathrm{Mg}_{2} \mathrm{SiO}_{4}$ & - & - & $\sqrt{ }$ & $\sqrt{ }$ & $\sqrt{ }$ & - & - & - & - \\
\hline Diopside-CaMgSi ${ }_{2} \mathrm{O}_{6}$ & - & - & $\sqrt{ }$ & $\sqrt{ }$ & $\sqrt{ }$ & - & - & - & - \\
\hline Andradite- $\mathrm{Ca}_{3} \mathrm{Fe}_{2}\left(\mathrm{SiO}_{4}\right)_{3}$ & - & - & - & $\sqrt{ }$ & $\sqrt{ }$ & - & - & - & - \\
\hline $\begin{array}{l}\text { Diopside aluminian- }\left(\mathrm{Mg}_{0.851} \mathrm{Fe}_{0.026} \mathrm{Al}_{0.080}\right. \\
\left.\mathrm{Ti}_{0.003} \mathrm{Cr}_{0.040}\right)\left(\mathrm{Ca}_{0.720} \mathrm{Na}_{0.027} \mathrm{Mg}_{0.179} \mathrm{Fe}_{0.071}\right. \\
\left.\mathrm{Mn}_{0.003}\right)\left(\mathrm{Si}_{1.891} \mathrm{Al}_{0.109}\right) \mathrm{O}_{6}\end{array}$ & - & - & - & - & - & $\sqrt{ }$ & $\sqrt{ }$ & $\sqrt{ }$ & $\sqrt{ }$ \\
\hline
\end{tabular}

" $\sqrt{ }$ " indicates the presence of the phase, while "-_" indicates the absence of the phase

\subsection{SEM Analysis}

The SEM microstructure of Y900 is shown in Fig. 3. In Y900, EDS detected only magnesium, silicon and oxygen in the agglomeration with dark contrast (labeled "A"), suggesting that those agglomerates were protoenstatite $\left(\mathrm{MgSiO}_{3}\right)$, which is the decomposed product of talc. The lighter contrast reticular area (labeled "C") contained calcium, magnesium and silicon, suggesting that they were akemantite $\left(\mathrm{Ca}_{2} \mathrm{Mg}\left(\mathrm{Si}_{2} \mathrm{O}_{7}\right)\right)$ and diopside $\left(\mathrm{CaMgSi}_{2} \mathrm{O}_{6}\right)$ coupled with the $\mathrm{XRD}$ analysis results. Some regions (labeled "B") appearing bright white in BSI contained only more iron, magnesium and oxygen, suggesting that they were hematite $\left(\mathrm{Fe}_{2} \mathrm{O}_{3}\right)$ or/ and $\mathrm{RO}$ phase ( $\mathrm{FeO}-\mathrm{MgO}$ solid solution from steel slag). In Y900-b (the higher magnification), more aluminum were in the EDS spectra in the agglomerates labeled as "F", the crystals could be distinguished as clay relict. The granular crystals at the surface of "F", labeled as "D", enriched in $\mathrm{Si}, \mathrm{Ca}$ and $\mathrm{Al}$, suggesting that those crystals were anorthite $\left(\mathrm{Ca}\left(\mathrm{Al}_{2} \mathrm{Si}_{2} \mathrm{O}_{8}\right)\right)$. EDS of the region " $\mathrm{G}$ " and "E" revealed that they were protoenstatite $\left(\mathrm{MgSiO}_{3}\right)$ and akemantite $\left(\mathrm{Ca}_{2} \mathrm{Mg}\left(\mathrm{Si}_{2} \mathrm{O}_{7}\right)\right)$, respectively.
In Y1000 and Y1100, as BSI shown in Fig. 4, three types of agglomerates were observed. The block " $A$ " were protoenstatite $\left(\mathrm{MgSiO}_{3}\right)$, and decreased "B" were hematite $\left(\mathrm{Fe}_{2} \mathrm{O}_{3}\right)$ or/and $\mathrm{RO}$ phase compared with Y900. Region " $\mathrm{C}$ ", increased with the increasing sintering temperature, enriched $\mathrm{Ca}, \mathrm{Mg}$ and $\mathrm{Si}$, suggesting that they were diopside $\left(\mathrm{CaMgSi}_{2} \mathrm{O}_{6}\right)$. Details of "C" were presented at higher magnification (Y1000-b, Y1100-b). These fine crystalline (labeled "H") $(<2 \mu \mathrm{m})$ developed from the surface and the interface of the bulk crystals. In Y1100-b, the surface of the bulk were smooth (region "L"), suggesting the formation of a liquid in the matrix.

Figure 5 shows the SEM micrographs of Y1150, Y1200 and Y1220. It is observed starting densification porcelain in Y1150 consisting of club-shaped "A" (protoenstatite, $\mathrm{MgSiO}_{3}$ ), bulk "B" (hematite, $\mathrm{Fe}_{2} \mathrm{O}_{3}$ or/and RO phase), bond " $\mathrm{C}$ " (diopside alumina) and irregular pores. Little of iron existed as $\mathrm{Fe}_{2} \mathrm{O}_{3}$ or $\mathrm{FeO}$ could be found in BSI in Y1150-a. However, the bulk "B" were completely disappeared at $1200^{\circ} \mathrm{C}$, which means all hematite and $\mathrm{RO}$ phases had been transformed into other phases, such as glass phase. 

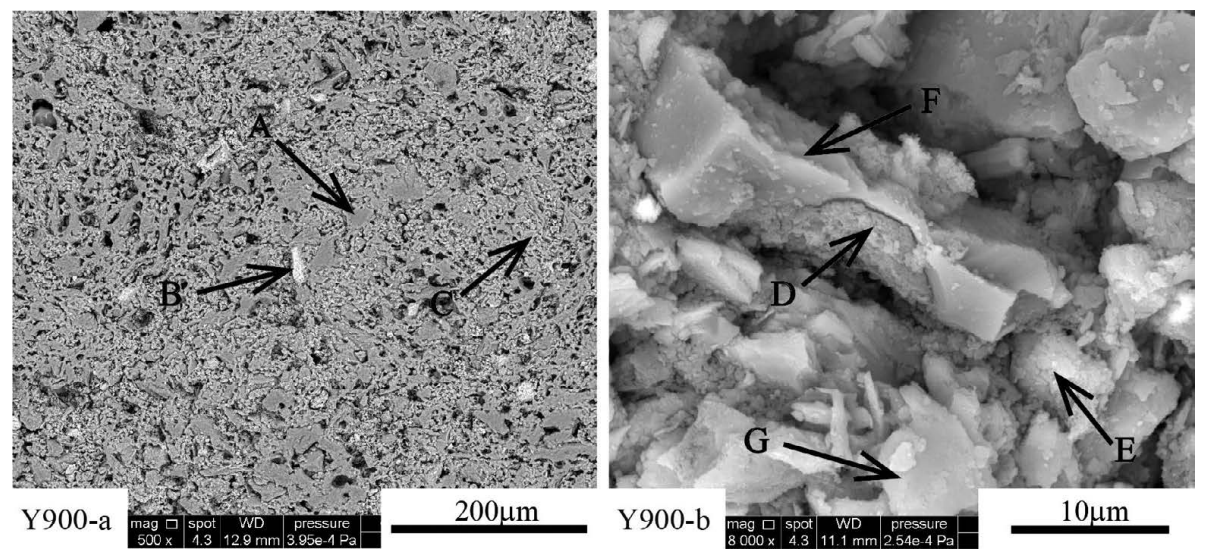

Fig. 3. SEM micrographs of $\mathrm{Y} 900$. Where: "A"- Protoenstatite $\left(\mathrm{MgSiO}_{3}\right)$, "B"- Hematite $\left(\mathrm{Fe}_{2} \mathrm{O}_{3}\right)$ or/and $\mathrm{RO}$ phase, "C"Ca-rich crystals, "D"- Anorthite $\left(\mathrm{Ca}\left(\mathrm{Al}_{2} \mathrm{Si}_{2} \mathrm{O}_{8}\right)\right)$, "E"- Akemantite $\left(\mathrm{Ca}_{2} \mathrm{Mg}\left(\mathrm{Si}_{2} \mathrm{O}_{7}\right)\right)$, "F"- Clay relict, "G"- Protoenstatite $\left(\mathrm{MgSiO}_{3}\right)$.
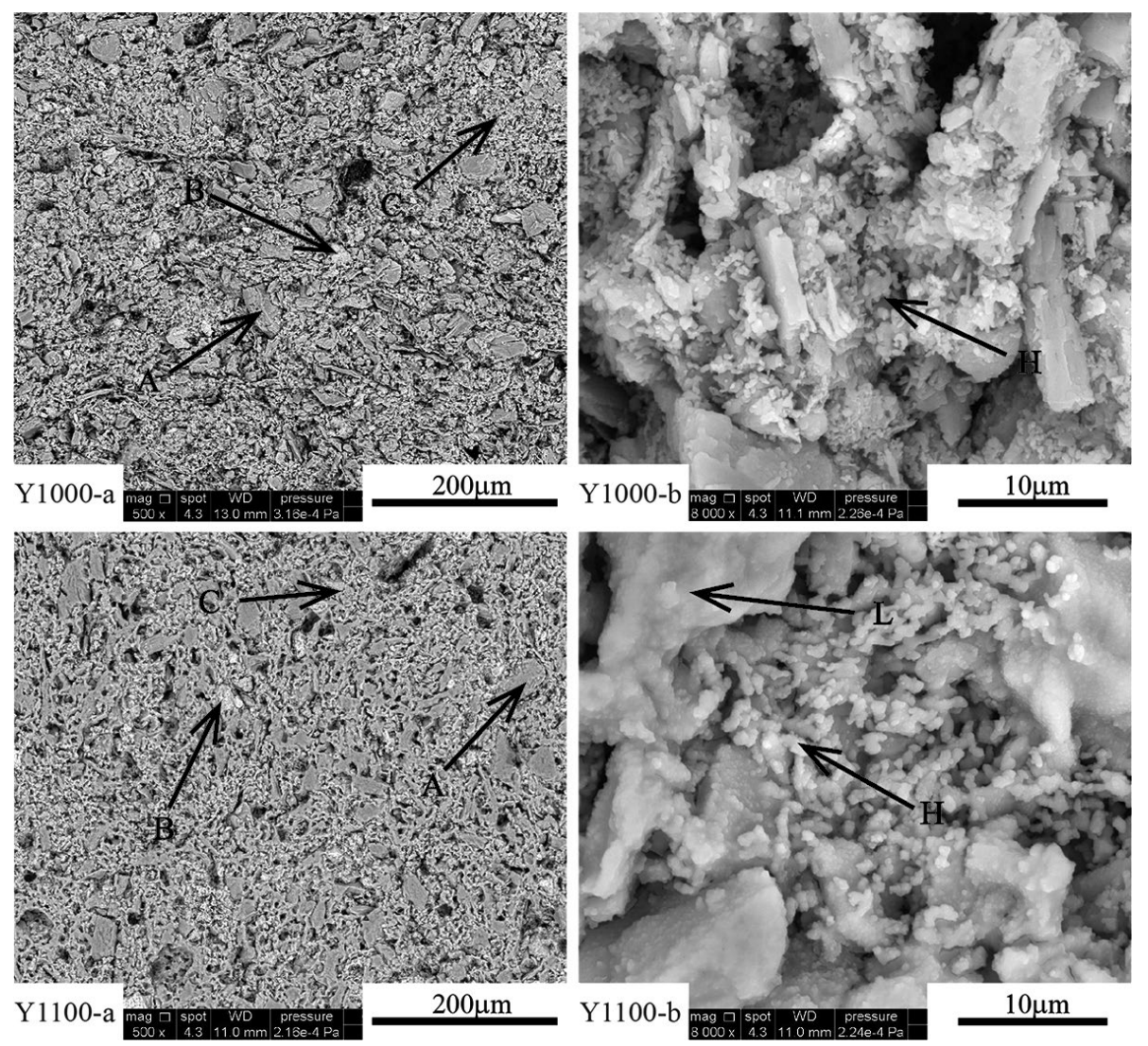

Fig. 4. SEM micrographs of $\mathrm{Y} 1000$ and $\mathrm{Y} 1100$. Where: "A"- Protoenstatite $\left(\mathrm{MgSiO}_{3}\right)$, "B"- Hematite $\left(\mathrm{Fe}_{2} \mathrm{O}_{3}\right)$ or/and $\mathrm{RO}$ phase, "C"- Ca-rich crystals, mainly Diopside $\left(\mathrm{CaMgSi}_{2} \mathrm{O}_{6}\right)$, "H" showing the fine Diopside crystalline developed from the surface and the interface of the bulk crystals, the smooth surface of "L" region suggesting the formation of a liquid in the matrix.

An almost uniform distribution of the club-shaped protoenstatite and diopside aluminian appeared in micrographs of Y1200-b and Y1220-b in Fig. 5. Higher magnification showed the presence of interlocking microstructure with average crystallite width of about $<5 \mu \mathrm{m}$. Clear glassy matrix were seen in Y1220, which etched under the same condition, suggesting more liquid formation. The circular trend pores also proved this.

\section{Discussion}

A magnified XRD patterns of $\mathrm{Y} 700$ to $\mathrm{Y} 1150$ at $2 \theta=20^{\circ}-$ $50^{\circ}$ were shown in Fig. 6 in order to more clearly illustrate the changes of calcium-rich and iron-rich crystalline phases with increasing sintering temperature. The Ca-rich crystals including anorthite, akermanite, diopside and diopside aluminian were indicated as down solid arrow, and the Fe-rich crystals including hematite and andradite were indicated as up hollow arrows. All Ca-rich crystals, akemantite, anorthite and diopside start forming at temperature from $700^{\circ} \mathrm{C}$ 

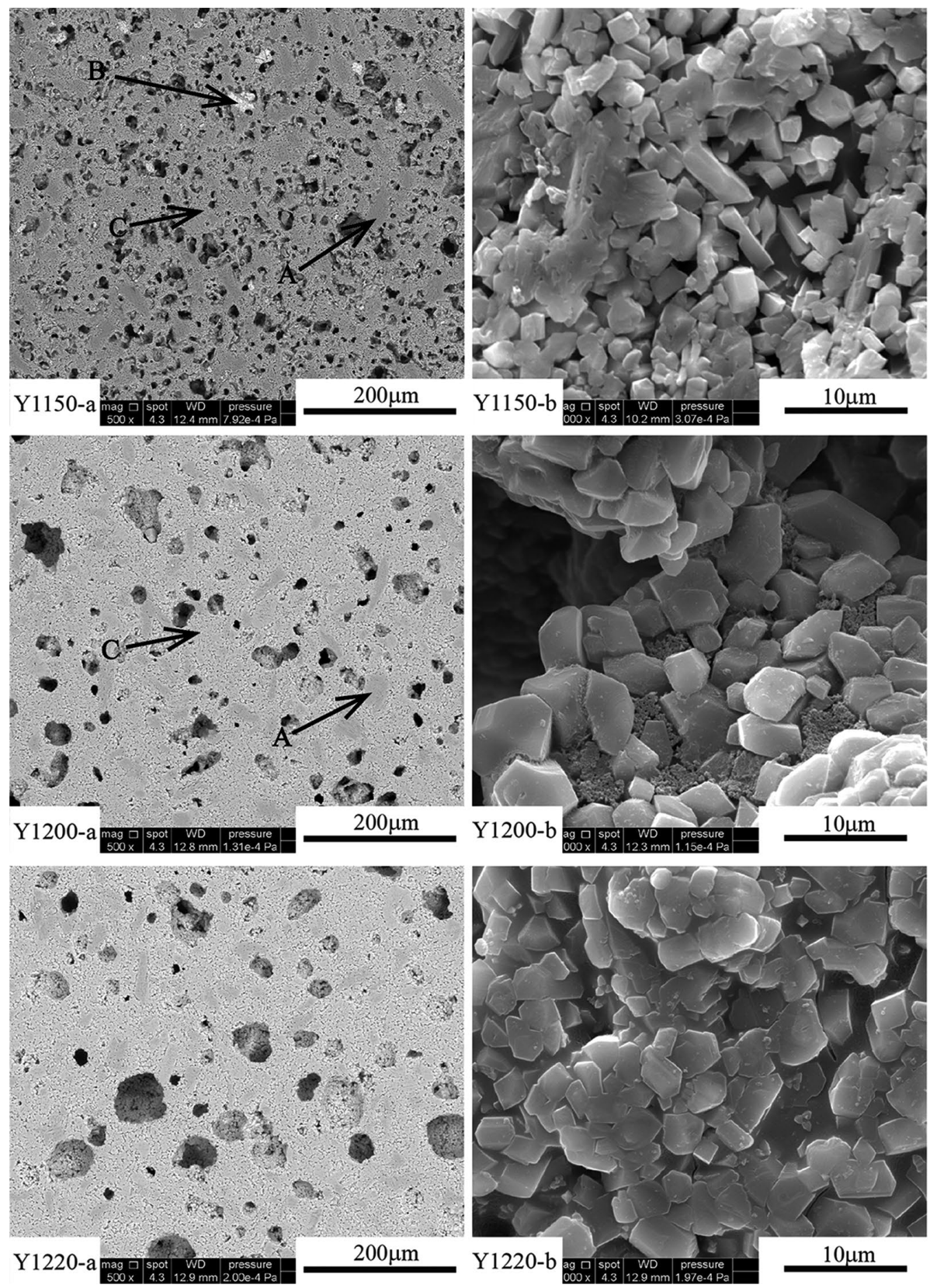

Fig. 5. SEM micrographs of $Y 1150$, $\mathrm{Y} 1200$ and $\mathrm{Y} 1220$. Where: "A"- Protoenstatite $\left(\mathrm{MgSiO}_{3}\right)$, "B"- Hematite $\left(\mathrm{Fe}_{2} \mathrm{O}_{3}\right)$ or/ and $\mathrm{RO}$ phase, "C"- Ca-rich crystals, mainly Diopside $\left(\mathrm{CaMgSi}_{2} \mathrm{O}_{6}\right)$.

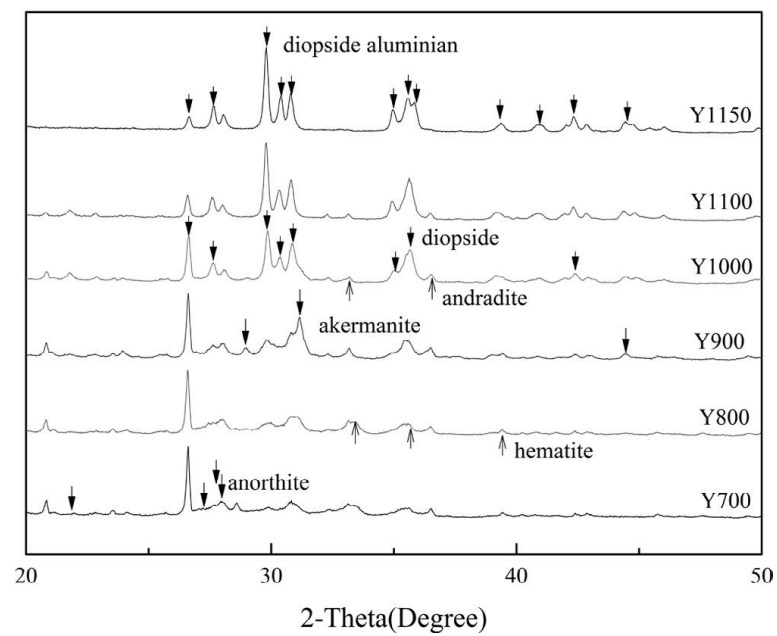

Fig. 6. Changes of Ca-rich and Fe-rich crystals at different sintering temperatures. to $800^{\circ} \mathrm{C}$. High $\mathrm{CaO}$ composition derived from steel slag contributes to crystallization in low temperature. With diffusion of components in ceramics, akemantite transformed into diopside at approximately $1000^{\circ} \mathrm{C}$, which obviously increased the amount of diopside, as shown in the changes of peaks from Y900 to Y1000 in Fig. 6.

In a view of the above analyses, the sintering process at lower temperatures (below $1100^{\circ} \mathrm{C}$ ) may be described as Eqs. (4) to (12). Gibbs free energy changes $(\Delta G)$ of Eqs. (8) to (12) in the range of $700^{\circ} \mathrm{C}$ to $1300^{\circ} \mathrm{C}$ were calculated and shown in Fig. 7. The thermodynamic calculation indicated that the $\Delta G$ of Eqs. (8) to (12) reactions were all of negative values at temperature above $700^{\circ} \mathrm{C}$, illustrating the existence of these reactions.

$$
\mathrm{CaCO}_{3} \rightarrow \mathrm{CaO}+\mathrm{CO}_{2}
$$




$$
\begin{array}{r}
\mathrm{Ca}(\mathrm{OH})_{2} \rightarrow \mathrm{CaO}+\mathrm{H}_{2} \mathrm{O} \\
3 \mathrm{MgO} \cdot 4 \mathrm{SiO}_{2} \cdot \mathrm{H}_{2} \mathrm{O} \rightarrow 3 \mathrm{MgSiO}_{3}+\mathrm{SiO}_{2}+\mathrm{H}_{2} \mathrm{O} \\
\mathrm{Al}_{2} \mathrm{O}_{3} \cdot 2 \mathrm{SiO}_{2} \cdot 2 \mathrm{H}_{2} \mathrm{O} \rightarrow \mathrm{Al}_{2} \mathrm{O}_{3} \cdot 2 \mathrm{SiO}_{2}+\mathrm{H}_{2} \mathrm{O} \\
\mathrm{MgSiO}_{3}+2 \mathrm{CaO}+\mathrm{SiO}_{2} \rightarrow \mathrm{Ca}_{2} \mathrm{Mg}\left(\mathrm{Si}_{2} \mathrm{O}_{7}\right) \ldots \ldots
\end{array}
$$

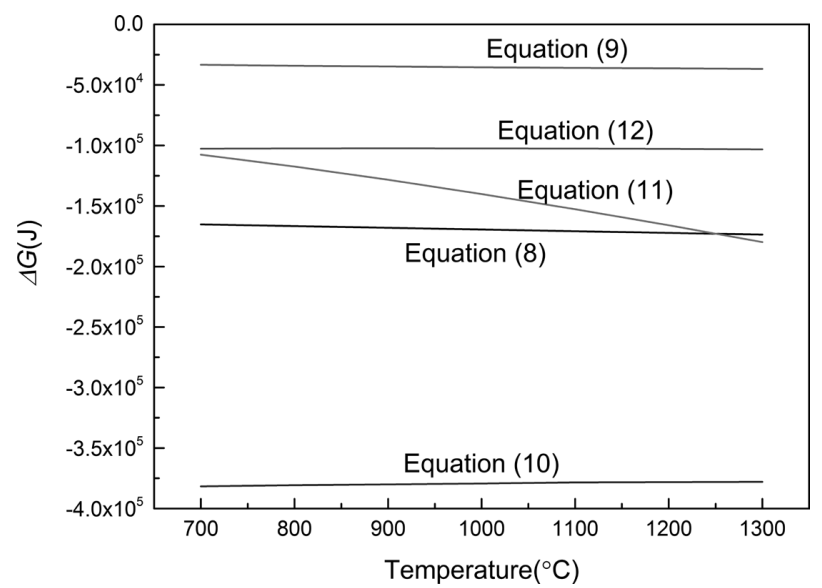

Fig. 7. Gibbs free energy changes $(\Delta G)$ of Eqs. (8) to (12) in the temperature range from $700^{\circ} \mathrm{C}$ to $1300^{\circ} \mathrm{C}$.

$$
\begin{aligned}
\mathrm{MgSiO}_{3}+2 \mathrm{CaO} \cdot \mathrm{SiO}_{2} & \rightarrow \mathrm{Ca}_{2} \mathrm{Mg}\left(\mathrm{Si}_{2} \mathrm{O}_{7}\right) \ldots \ldots . . . . . \\
\mathrm{CaO}+\mathrm{Al}_{2} \mathrm{O}_{3} \cdot 2 \mathrm{SiO}_{2} & \rightarrow \mathrm{CaAl}_{2} \mathrm{Si}_{2} \mathrm{O}_{8} \ldots \ldots \ldots . . . \\
\mathrm{Ca}_{2} \mathrm{Mg}\left(\mathrm{Si}_{2} \mathrm{O}_{7}\right)+\mathrm{MgSiO}_{3}+\mathrm{SiO}_{2} & \rightarrow 2\left(\mathrm{CaMgSi}_{2} \mathrm{O}_{6}\right) \ldots \\
\mathrm{CaO}+\mathrm{MgSiO}_{3}+\mathrm{SiO}_{2} & \rightarrow \mathrm{CaMgSi}_{2} \mathrm{O}_{6} \ldots \ldots \ldots .
\end{aligned}
$$

Considering the Fe-rich crystals, hematite derived from steel slag, but andradite generated at $1000^{\circ} \mathrm{C}$ from $\mathrm{Fe}$ rich areas in ceramics. Peaks of andradite and $\mathrm{Fe}_{2} \mathrm{O}_{3}$ or RO phases disappeared at approximately $1150{ }^{\circ} \mathrm{C}^{29,30)}$ and $1180^{\circ} \mathrm{C}$, respectively, and no other Fe-rich crystal formed except the solution of some iron into diopsite aluminian. So it could be inferred that most Fe-rich crystals melted and became liquid in ceramics at temperature above $1150^{\circ} \mathrm{C}$. BSI and EDS analysis also proved that $\mathrm{Fe}_{2} \mathrm{O}_{3}$ or/and RO phases were not involved in the sintering reaction at temperature below $1100^{\circ} \mathrm{C}$, but decreased from $1100^{\circ} \mathrm{C}$ to $1150^{\circ} \mathrm{C}$.

As shown in Fig. 2, in stage I, the crystallization process was preliminary completed. Therefore, stage I was named as primary crystallization process. It is obvious that a crystallization process in stage $\mathrm{I}$ is significantly prior to the densification process in stage II (as shown in Fig. 1). This is in favor of stable sintering because the resulting crystals

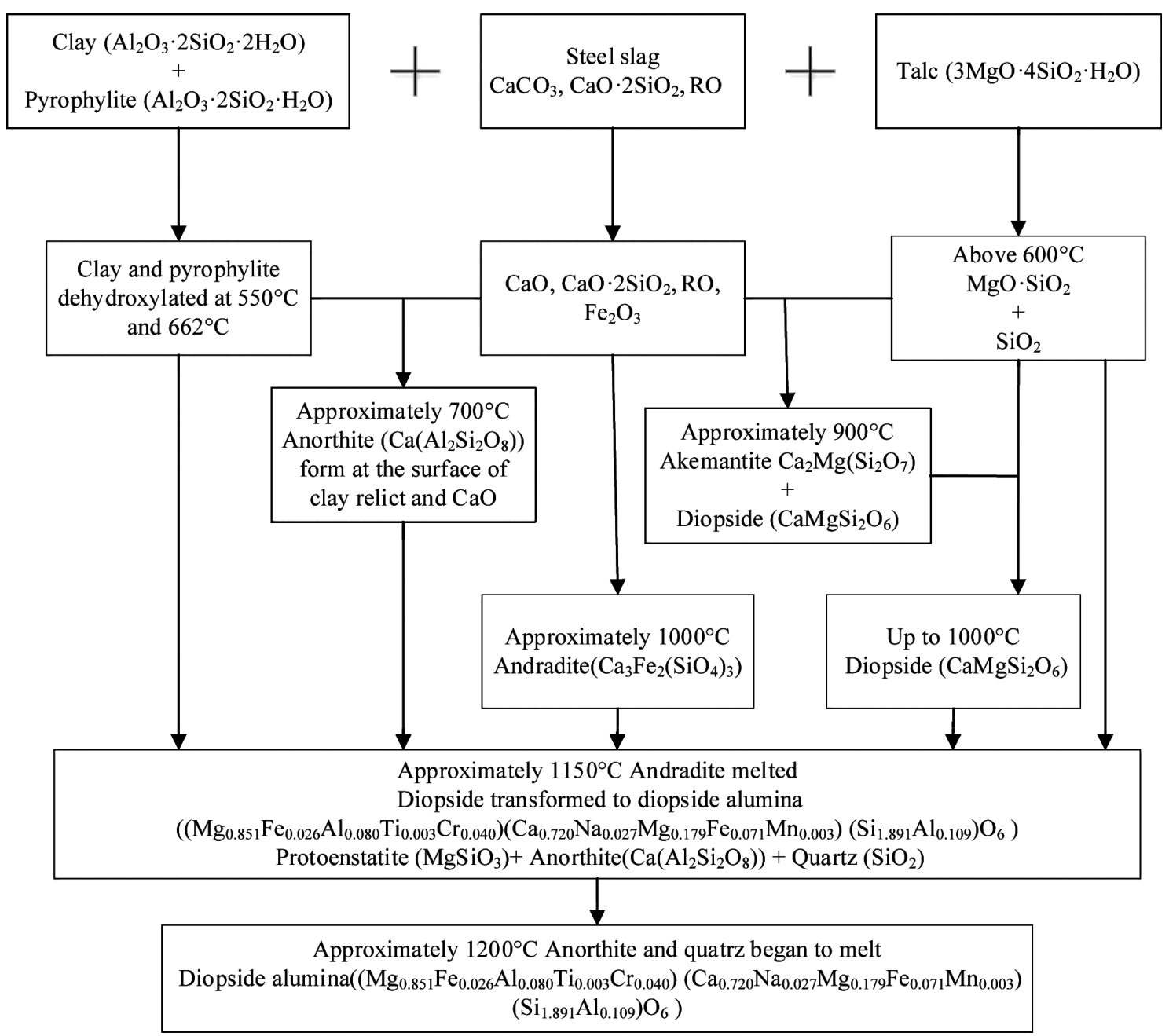

Fig. 8. Box diagram of phase evolution in pyroxene porcelain, based on XRD, SEM, physical and mechanical results. 
would play a role of framework in ceramics during the densification process.

As analyzed above, Ca-rich crystals generated at lower temperatures, and akemantite is an intermediate phase and will be converted into diopside due to the surplus of $\mathrm{MgSiO}_{3}$ and $\mathrm{SiO}_{2}$.

Stage II showed that the densification process started at $1100^{\circ} \mathrm{C}$ and finish at $1220^{\circ} \mathrm{C}$, which is owing to the formation of liquid in ceramics. Meanwhile, a secondary crystallization would happen in stage II. Dioposide $\left(\mathrm{CaMgSi}_{2} \mathrm{O}_{6}\right)$ changed into dioposide aluminan at $1150^{\circ} \mathrm{C}$ with ions of $\mathrm{Na}, \mathrm{Fe}, \mathrm{Al}, \mathrm{Ti}, \mathrm{Cr}$ and $\mathrm{Mn}$ coming into crystal structure due to the promoted diffusion of ions under liquid sintering process. Therefore, sole well crystallized pyroxene phases composed the final ceramics, which was contributed to their excellent mechanical performances. The solution of metal ions in stage II process is also a good news for the solidification of heavy metals.

Clay and pyrophylite dehydroxylated at $550^{\circ} \mathrm{C}$ and $662^{\circ} \mathrm{C}$, respectively. ${ }^{31)}$ They ensure the strength of the green body, and were the main sources of silicon element. The dehydroxylation of talc began at approximately $600^{\circ} \mathrm{C}$ and gradually decomposed to $\mathrm{MgSiO}_{3}$ and $\mathrm{SiO}_{2}$ at temperature between 800 and $900^{\circ} \mathrm{C}$. The rod-shaped $\mathrm{MgSiO}_{3}$ played a supporting role to prevent sample deformation during the sintering process. The main reaction of steel slag at temperatures below $900^{\circ} \mathrm{C}$ was calcium carbonate decomposition. High active $\mathrm{CaO}$ decomposed from $\mathrm{CaCO}_{3}$ contributed to crystallize at lower sintering temperature, facilitated the formation of akemantite, anorthite and diopside. The latter is an inosilicate of a simpler structure with respect to the tectosilicate. Consequently, the formation of diopside requires lesser structural rearrangements. ${ }^{32)}$ Akermanite, which is an interim nonequilibrium phase, formed at approximately $900^{\circ} \mathrm{C}$ and then transformed to diopside at approximately $1000^{\circ} \mathrm{C}$. Andradite formed at approximately $1000^{\circ} \mathrm{C}$ and melted at approximately $1150^{\circ} \mathrm{C}$, prompting the densification process, at the same time diopside transferred to diopside aluminian with more ions solution. At temperatures above $1220^{\circ} \mathrm{C}$, samples began to swell, sample completely lose shape at temperatures above $1250^{\circ} \mathrm{C}$. A box diagram of phase evolution in pyroxene porcelain, based on the present XRD and SEM study, is shown in Fig. 8.

\section{Conclusion}

Ceramics with high $\mathrm{CaO}$ and $\mathrm{Fe}_{2} \mathrm{O}_{3}$ content were prepared from steel slag and the samples sintered at $1220^{\circ} \mathrm{C}$ had good properties with flexural strength of $107 \mathrm{MPa}$ and water absorption of $0.045 \%$. High $\mathrm{CaO}$ composition of steel slag contributes to crystallization at low temperature. Akemantite, anorthite and diopside formed at approximately $700^{\circ} \mathrm{C}$ and diopside were predominant at $1000^{\circ} \mathrm{C}$. The resulting crystals played a role of framework in ceramics during the sintering process. $\mathrm{Fe}_{2} \mathrm{O}_{3}$ or RO phases did not participate in the sintering at temperature below $1150^{\circ} \mathrm{C}$. However, melting of iron-rich andradite at approximately $1150^{\circ} \mathrm{C}$ and $\mathrm{Fe}_{2} \mathrm{O}_{3}$ or RO phases at approximately $1180^{\circ} \mathrm{C}$ promoted the densification process. As a consequence, the crystallization process is significantly prior to the densification process. Diopside was predominant since approximately $1000^{\circ} \mathrm{C}$ and transformed to diopside aluminian at temperature above $1150^{\circ} \mathrm{C}$. Sole pyroxene phases composed the final ceramic, which were contributed to their excellent mechanical performances.

\section{Acknowledgement}

This work was financially supported by the National Natural Science Foundation of China (No. 51474027).

\section{REFERENCES}

1) China Resources Comprehensive Utilization annual report, National Development and Reform Commission, Beijing, (2014), 12.

2) B. Dhal, H. Thatoi, N. Das and B. Pandey: J. Hazard. Mater., 250 (2013), 272.

3) E. A. Oluwasola, M. R. Hainin and M. M. A. Aziz: Jurnal Teknologi, 70 (2014), 117.

4) P. Tsakiridis, G. Papadimitriou, S. Tsivilis and C. Koroneos: J. Hazard. Mater., 152 (2008), 805.

5) C. Barca, C. Gérente, D. Meyer, F. Chazarenc and Y. Andrès: Water Res., 46 (2012), 2376.

6) G. Wang, Y. Wang and Z. Gao: J. Hazard. Mater., 184 (2010), 555.

7) J. Yu and K. Wang: Energy Fuel, 25 (2011), 5483.

8) D. Mombelli, C. Mapelli, S. Barella, A. Gruttadauria, G. Le Saout and E. Garcia-Diaz: J. Hazard. Mater., 279 (2014), 586.

9) Z. Li, S. Zhao, X. Zhao and T. He: J. Hazard. Mater., 199 (2012), 448.

10) Q. Wang, P. Yan and J. Feng: J. Hazard. Mater., 186 (2011), 1070.

11) S. Qin and B. Wu: J. Hazard. Mater., 198 (2011), 269.

12) E. Furlani, G. Tonello and S. Maschio: Waste Manag., 30 (2010), 1714.

13) E. Karamanova, G. Avdeev and A. Karamanov: J. Eur. Ceram. Soc., 31 (2011), 989.

14) K. Dana and S. K. Das: J. Eur. Ceram. Soc., 24 (2004), 3833.

15) V. M. Sglavo, S. Maurina, A. Conci, A. Salviati, G. Carturan and G. Cocco: J. Eur. Ceram. Soc., 20 (2000), 245.

16) T. Yoshikawa, S. Hirano, N. Hirai and T. Tanaka: ISIJ Int., 48 (2008), 1322.

17) W. Dai, Y. Li, D. Cang, Z. Liu and Y. Fan: ISIJ Int., 54 (2014), 2672.

18) I. Ozdemir and S. Yilmaz: J. Mater. Process. Technol., 183 (2007), 13.

19) L. M. Schabbach, F. Andreola, L. Barbieri, I. Lancellotti, E. Karamanova, B. Ranguelov and A. Karamanov: J. Eur. Ceram. Soc., 32 (2012), 2843

20) N. Y. Mostafa, A. A. Shaltout, M. S. Abdel-Aal and A. El-maghraby: Mater. Design, 31 (2010), 3677.

21) H. Badiee, A. Maghsoudipour and B. Raissi Dehkordi: Adv. Appl. Ceram., 107 (2008), 111

22) X. B. Ai, H. Bai, L. H. Zhao, D. Q. Cang and Q. Tang: Int. J. Miner Metall. Mater., 20 (2013), 379

23 X. B. Ai, Y. Li, X. M. Gu and D. Q. Cang: Adv. Appl. Ceram., 112 (2013), 213.

24) L. Zhao, Y. Li, Y. Zhou and D. Cang: Mater. Des., 64 (2014), 608.

25) M. Cameron and J. J. Papike: Am. Mineral., 66 (1981), 1.

26) F. J. Torres and J. Alarcón: J. Non-Cryst. Solids, 347 (2004), 45.

27) ISO 10545-3:1995, Ceramic tiles -- Part 3: Determination of water absorption, apparent porosity, apparent relative density and bulk density.

28) ISO 10545-4:2014, Ceramic tiles -- Part 4: Determination of modulus of rupture and breaking strength.

29) Y. Suwa, Y. Teltal and S. Nere: Am. Mineral., 61 (1976), 26.

30) R. K. Eby, R. C. Ewing and R. C. Birtcher: J. Mater. Res., 7 (1992), 3080.

31) Y. Iqbal and W. E. Lee: J. Am. Ceram. Soc., 83 (2000), 3121.

32) L. Barbieri, F. Bondioli, I. Lancellotti, C. Leonelli, M. Montorsi, A. M. Ferrari and P. Miselli: J. Am. Ceram. Soc., 88 (2005), 3131. 